\title{
The Politics of Space, Race and Class
}

April 2011: Finally I had a Saturday off and I decided to go to the wealthy eastern part of Caracas together with a friend. I had planned on doing this for a long time, but I never found the time. During all my stays in Venezuela I probably spent 95 percent of my time in the western part, the poor part, in Municipio Libertador. My axis of movement, my comfort zone, went from the middle of Sabana Grande crossing over to Plaza Venezuela and moving on toward Parque Central, to Plaza Bolívar and continuing to the presidential palace of Miraflores on the outskirts of the city center, and from there on to the barrios stretching out to the west. The west is a place of both great pains and great pleasures, of overcrowded streets and overcrowded houses, of yelling street vendors and deathdefying motorizados (motorcycle drivers), of aggressive traffic jams and honking camionetas (small buses), of shouting and music and car horns during the day and the occasional gun shot at night, of cheap restaurants and street stalls surrounded by the odor of frying oil, of the sweet smell of garbage rotting in the street, of murales (stencils and artistic graffiti) and political slogans on the walls, of pro-government politics and people dressed in red T-shirts, of the pains of poverty and the resilience that accompanies it. This was what I knew. On this motorcycle trip I was finally about to see another side of Caracas.

The city of Caracas is squeezed into a narrow valley and can be crossed from one end to the other quite quickly (at least hypothetically, if one ignores the congested traffic). We rapidly crossed the city on 
our motorbike via the highway going through Municipio Chacao and Municipio Baruta. As we raced between the cars, the city became notably more spacious, cleaner and more orderly. In the east, we reached the entrance to El Hatillo. This municipality of about 70,000 inhabitants is conformed both by high-class residential areas and by low-class neighborhoods in the valleys to the north. A large Welcome to El Hatillo sign greeted us in both English and Spanish. The road climbing up to the sector called Los Naranjos was steep and windy with upscale residential apartment buildings hovering over the sides of the hills. The motorbike was working hard to get us up the hill. On the way up I only saw one graffiti on a wall. It read: "Hugo, me cago en tus leyes" [Hugo, I shit on your laws].

As we finally made it to the top, we stopped for a drink at a roadside kiosk. Outside the kiosk was a giant stack of opposition newspapers, El Nacional and El Universal, while two copies of the pro-government newspaper Diario Vea were half-hidden on the news stand. There was almost no one to be seen, just a few nice-looking cars driving by. The apartment buildings were surrounded by gates and protected by a uniformed guard at the entrance. On the other side of the valley we could see some giant mansions, scattered around the lush landscape. The abundance of green bushes and vegetation around us gave the area an airy, fresh feeling - a stark contrast to the east, where almost no green space can be seen.

We got back on the motorbike and continued upward, until we reached the Centro Commercial Los Naranjos, a mid-size exclusivelooking shopping mall hovering over the valley. As we continued up the road, we reached the entrance to a gated community on the right-hand side. Behind the gates we got a glimpse of a white mansion built as a copy of the White House in Washington. I wanted to go closer to get a picture, but we were well aware that two people on a motorbike taking photos would probably raise fear here, and I was worried that if we got any closer the guard at the entrance would call the police before our roadtrip had even begun. So we continued upward and east, toward La Lagunita, one of the really posh neighborhoods. Along the road continued the nice-looking, well-maintained apartment buildings and the gated mansions. Still, curiously, almost no people could be seen. We finally reached La Lagunita Country Club, one of the private leisure clubs for the really rich, complete with a golf course that could be barely seen behind the gates. Reaching the end of the golf course we passed through a small roundabout and continued into another really upscale 


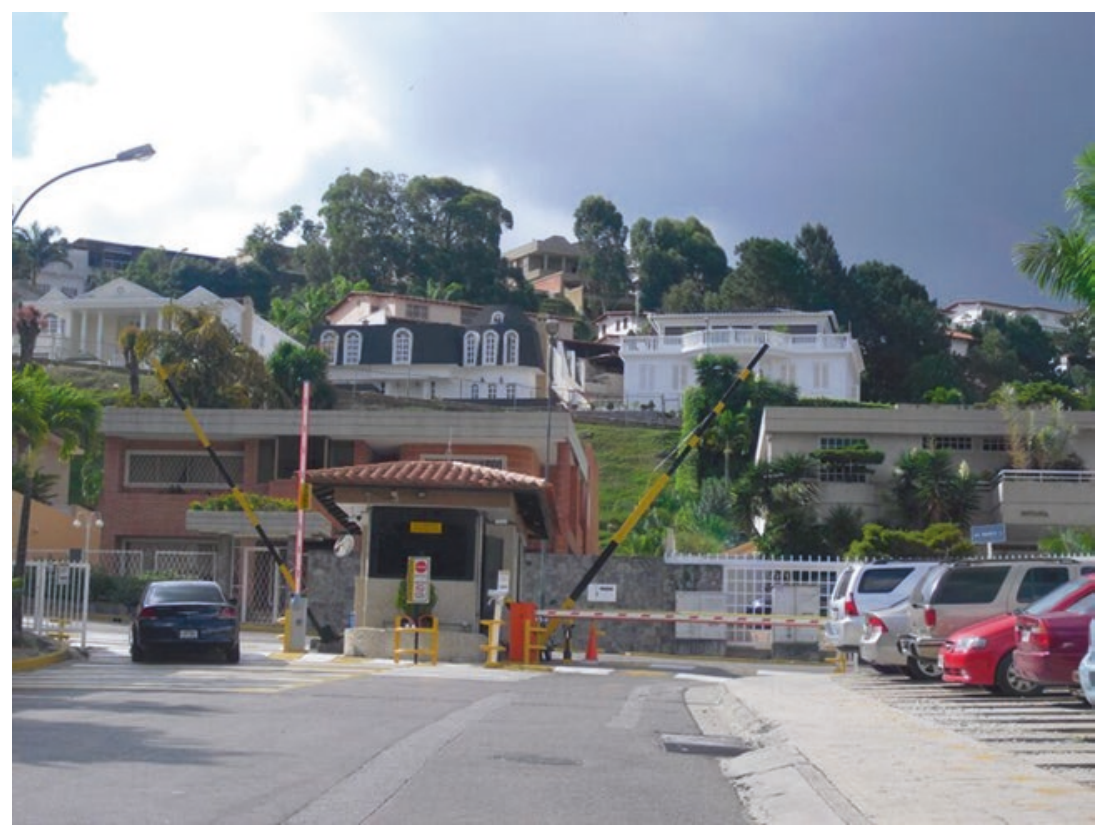

Photo 4.1 Private homes in Eastern Caracas. Photo by the author

neighborhood. Huge mansions were scattered along the road, many with garages that could fit five to six cars, and most of them surrounded by high gates and barbed wire. Many had security cameras, making us feel like intruders even though we had nothing bad in mind. The mansions had broad frontyard patios in marble and ceramic, well-kept gardens and lush vegetation. Swimming pools were hidden in the backyards. The cars that were parked in the front of these houses were all shiny and polished, most of them $4 \times 4-$ a necessary status symbol for anyone who can afford it. And there it was again; another replica of the White House. I just had to take a photo. So we passed the house on our motorbike one more time while I tried to take the picture as fast as I could, still worried that someone would see us and call the police.

For the next hour we cruised around the area. Up and down the hill, the gated mansions continued, one more luxurious than the next. At the end of the valley we encountered another huge private gated club, complete with several tennis courts and large green areas stretching up the hillagain there was no one in sight. And there was another shopping mall, 
with another "White House" on the other side of the road, and another exclusive-looking gated community that we didn't dare to approach. The cars that passed us were all shiny, new and expensive. Only a few times did we pass a camioneta, and those we saw had a sign announcing that they went all the way to Casalta 3-at the far end of the other side of town, where I lived. But the camioneta was not for the people who lived in El Hatillo, it was for their domestic servants, mostly women, but also a few men who were probably guards and gardeners. They were looking tiredly out of the window, all of them notably darker than the few locals we saw. My friend commented that a friend of his who worked as a delivery boy once had the door opened in this neighborhood by a woman that was dressed in a black-and-white domestic servant uniform as in the television soap operas, complete with the hair cap and everything. I didn't even want to think of how early you had to get up in the morning if you were to cross Caracas from a western barrio up to El Hatillo by bus.

In the afternoon, we went back to the shopping mall Los Naranjos. On the way up to the food court we passed two TV personalities. We sat down at an Asian restaurant, starving after the long trip. Next to us were two women and a teenage girl eating sushi. One of the women, probably in her thirties, was talking in a loud voice about her recent return trip from Miami and how the plane had been delayed from a stop-over in Panama and how her father had called the airline company to demand to know where she was. Three teenage boys were sitting at another table with a "fuck the world" expression on their faces, all dressed in trendy, expensive sporting clothes, fiddling with their Blackberries (another status symbol) and eating sushi. On the other side of the room a group of people had occupied two tables. They were all fair-skinned, well-dressed and self-confidently gesticulating - with the exception of one person around the table, the darker-skinned nanny that they had brought with them to occasionally hold one of the toddlers. So as to make it clear that she was not one of them, she was dressed in the kind of shirt that the women who work in kindergartens use - a blue overall with prints of dancing bears on. Her hair was up in a bun. The hair of the other women looked shiny and perfect as if it had just been done by the hairdresser. In the west of Caracas, the nanny could have been my next-door neighbor, or any woman in the street; here she stood out, the only one in the group with mixed-race features marked by a hard life, sitting quietly and with a bent back.

It was getting late. We got back on the motorbike again and slowly descended the long and winding road down to the middle-class area of El Cafetal. If I turned my head to the right, I could see Petare, perhaps 
some two kilometers away in air distance. Petare is said to be the largest shantytown in Latin America, located in Municipio Sucre, on the border between Distrito Capital and Estado Miranda. As a displaced pincushion it lay there, thousands of red brick ranchos and spiderweb-like telephone and electricity cables sprawling up the mountain right next to the otherwise wealthy sectors in the east. From Petare comes a steady stream of news reports of murders and robberies and houses that are falling apart when it rains, but it is also conveniently close to its richer neighborhoods and a source of labor for bars and restaurants, shops and services, domestic servants and private guards.

As we reach the highway and the border of the El Hatillo Municipality, there is a sign welcoming us back, in both Spanish and English. There is also a blue sign-apparently set up by the municipality-asking: "Is your vehicle insured?" It was probably a reminder for the good people of El Hatillo that they were now leaving the safe haven of their gates and guards, and entering the dangerous jungle that is the rest of Caracas.

The contrast between wealth and poverty in Caracas is glaring for any visitor. The physical features of Caracas, cramped into a narrow valley, make it even more evident. Paradoxically, when traveling on the highway from the international airport of Maiquetia, along the coast and then into the city of Caracas, one inevitably has to pass the enormous, sprawling shantytown hills of, among others, Gramoven, Carretera Vieja, El Limón and 23 de Enero. A friend of mine once said that rich people, rushing by in their SUVs on their way home to eastern Caracas, probably just close their eyes when they pass these communities, pretending they are not there. Maybe that is true. Or perhaps they do see them, but what they see is "the space of the others": something that doesn't concern them or is part of their life world.

But the two extremes of Venezuelan society, the opulent mansions in the east and the ramshackle ranchos (shacks) in the west, are like two sides of the same coin. People's lives on either side of town are bound together by a common past, shaped by the twists and turns of politics, history and life. As discussed in previous chapters, Venezuela was shaped by oil flowing into a society structured by its colonial past. If we can grasp the consequences this had on creating different social groups inhabiting completely different life worlds, we are one step closer to understanding the underlying conflict shaping political processes in the Chávez era. 


\section{Manifestations of Social Inequality}

Viewing the physical habitat as a surface expression of much deeper social histories and historical-political developments, the city-valley of Caracas is, more than anything else, a testament to the unequal distribution of riches and radical differences in life quality that characterize not only Venezuela, but also the entire continent. Deep poverty and overwhelming luxury are found side by side, as in most Latin American cities. This is nothing new, but rather a basic feature of the continent since colonial times. Latin America and the Caribbean is the region of the world with the highest levels of inequality, characterized by three main features: "[inequality] is high, it is persistent, and it reproduces itself within a context of low socioeconomic mobility" (UNDP 2010:19).

The continental shift to neoliberal policies in the 1980s dramatically exacerbated social inequalities. Contracted economies, a downscaling of the productive sectors of the economy with the subsequent contraction of job markets, de-regulation and privatization of basic services and the reduction of social spending all led to increasing poverty rates and more social inequalities. As part of this process of social disruptions and economic changes, a redrawing of spatial and social maps has been taking place in urban centers in recent decades. The essence of these recent urbanization processes are new forms of spatial segregation and social discrimination, whereby those who can afford it, that is, the middle and upper classes, increasingly withdraw from public spaces in favor of building "exclusive, fortified enclaves for their residence, work, leisure, and consumption" (Caldeira 2000:1).

Caracas is no different in this respect. Those who can afford it live in mansions, gated communities and closed-off condominiums, pass their leisure time in expensive private clubs, use private transportation, send their children to expensive private schools and use private medical facilities. Vacations are spent in the USA, preferably Miami, and in Europe, Aruba, the Dominican Republic, or other high-class destinations. These are possibilities and places that are inaccessible for the poor. As a consequence, there are few or no spaces left for public interaction between those at the bottom and those at the top of the class hierarchy. The predominant types of cross-class encounters are those between employer and employee, and service buyer and service provider. "The rich" know "the poor" only as their employees, security guards, maids, bartenders, 
waitresses and shop keepers. There are few or no arenas in which different social classes mingle and few or no spaces that are non-hierarchical or have the potential to transgress class boundaries. The only spaces where different social classes can potentially mingle are the shopping malls. Thus, paradoxically, the consumer capitalism following the de-industrialization that drove social classes even more apart is also the force uniting themon the surface at least.

\section{Stratified Media Spaces}

The increasing monopolization and privatization of media and communication further reduced spaces available for public debate and deliberation (Fernandes 2010:2), strengthening the domination of the worldview and the interests of the powerful. This is also the case in Venezuela, where the media, contrary to what the opposition and national and international media commonly claim, was overwhelmingly dominated by private actors also under Chávez's rule (Weissbrot and Ruttenberg 2010; BBC 2012; Sapiezynska 2017:207).

Mixing media ownership and political and economic interests in a manner that would in no way be acceptable in Europe, media moguls in Latin America, including Venezuela, hold an enormous power-not only in furthering their own interests, but also in defining perceptions of citizenship and society. It was only after Chávez came to power that dark-skinned, poor people became legitimate protagonists in Venezuelan media, through governmental and grassroots media (Schiller 2011). The private channels are still displaying predominantly white people, and if colored and poor people are portrayed, it is more often than not as fools, villains or victims in news reports or soap operas.

\section{Cleavages Revealed}

"Chávez destroyed the harmonious society that we once had," was one of the truisms repeatedly stated by Chávez's opponents. This statement can be taken as a testament to the affluent minority's lack of knowledge about the lives of the poor. As one female Chávez's supporter worded it:

They [the opposition/middle- and upper class] never knew anything about the living conditions in the rest of the society. They didn't have to use public transport because they had their own cars. They didn't need to use public 
hospitals because they were insured at private clinics. They didn't have to care about pensions or social security because they had money. They didn't have to worry about crime because they had their private security firms. They knew nothing about all this and they don't understand what is happening here because they don't understand the background for it. It is like Chávez once said: even if we placed the opposition on a pedestal covered with diamonds, they would still hate us.

Chávez's coming to power laid bare the existing cleavages in Venezuelan society, at the same time as these cleavages were exacerbated by the ensuing political struggle between different social groups and classes. As the Chávez government provided the poor and colored with a renewed status, self-confidence and visibility in Venezuelan society, deep-seated and racialized stereotypes and prejudices against "the poor" became highly accentuated among the whiter and wealthier. At the same time, government supporters framed their antagonism against the elites in politically charged terms, criticizing the middle classes for being "bourgeois" parasites as well as traitors of national interests. Underlying these conflicts were deep racialized tensions harking back to the country's colonial formation.

\section{The Salience of Race}

The issue of race is an under-communicated, yet omnipresent feature of Venezuelan society. "Here in Venezuela there is no racism," people sometimes told me. "Here we all mingle." Nothing could be further from the truth. From the blonde European-looking women in skimpy bikinis figuring on the ever-present propaganda posters for the beer brand Polar, to people's vernacular conception of beauty; from the overwhelming whiteness of private media celebrities, to the differences in skin color between people in pro-opposition marches and people in pro-government marches: skin color is a vehicle through which racial hierarchy and prejudices speak.

The hierarchicalization of people based on color and race in Latin America has deep historical roots dating back to the Spanish invasion of indigenous land, the import of African slaves and the political conquest and domination of the continent constituting the Europeans as the superior victors. The white Spaniards constituted themselves as a race superior to those of black and indigenous people: a belief that found support 
in religion, politics and scientific beliefs at the time (see Harrison 1995; Hoffman and Centeno 2003; Mullings 2005).

In the post-emancipation period, Venezuelan elites regarded blacks as inferiors because they were associated with their status as slaves, perceived of as a separate cast designed to work for the whites (Wright 1990:5). Hence, the elites did not consider themselves racist, but rather attributed their contempt for blacks to the fact that they were poor-a just socio-economic classification in the elites' eyes, rather than a racial categorization (Wright 1990:5). However, black and colored people held important positions among regional and national elites after Venezuela's independence in 1830. The lack of a strong central state allowed black and colored individuals to establish themselves as regional caudillos through using military might, and pardos (the term used to describe the racial amalgam of Europeans, blacks and Indians) were found in the federal agencies and military organizations (Wright 1990:10).

\section{The Myth of Racial Democracy}

In the 1890s, leading Venezuelan intellectuals talked about the need to "whiten the race" by encouraging the immigration of white Europeans, while blocking the immigration of non-whites (Wright 1990:2; Tinker 2009:133; Derham 2010:69). Attributing racial dispositions to genetic deficiencies (Derham 2010:69) they didn't perceive blacks and pardos as compatible with democratic self-rule, and advocated for a strong centralist government that they eventually found in Juan Vicente Gómez's regime (Wright 1990:10). Following Gómez's death in 1935, the subsequent heads of state took a more "open-minded" stance on the correlations between race and democratic inclinations, allowing Acción Democrática to form its party with a leadership drawing from mixed-race and middle-class groups. Moreover, Acción Democrática soon found alliances with pardos and blacks (Wright 1990:10), turning the notion of racial democracy into their official party ideology (Wright 1990:11). These changes were seen as threatening by the white elites, not necessarily because of the threat of color, but rather because of the threat of the mobilization and rise of the lower classes (Wright 1990:11). Immigration processes driven by the bourgeoning oil industry also raised a lot of controversy. Leading intellectuals were overtly concerned with the dangers 
of colored immigration, as the oil industry attracted workers both of North American, European, Asian and Afro-West Indian origins (Wright 1990:132-133).

\section{Disposable SaVages}

However, as Acción Democrática and COPEI consolidated their governance following 1959, racial democracy gradually became the dominant official ideology, sustained by a populist-nationalist hegemony. This provided the Venezuelan lower and predominantly colored classes with a legitimate position in the lower end of the social hierarchy during the Fourth Republic until the social breakdown in the 1980s. They were portrayed as el pueblo; "as virtuous, albeit ignorant, and therefore in need of guidance" (Coronil and Skurski 2006:199). This perception changed notably as social conflict increased in the 1980s and 1990s. The escalating tensions between the elites and the poor transformed el pueblo from a noble mass to an unruly mass that threatened the civilizatory harmony of the nation (Coronil and Skurski 2006). This shift brought out in the open the underlying colonial racial templates associating color with primitivism and inherent inferiority. As Coronil and Skurski demonstrate through a minute analysis of the public reactions to the Amparo massacre in 1988 and el Caracazo in 1989, both instances "made salient suppressed conceptions of the poor as disposable savages" (Coronil and Skurski 2006:123).

\section{The Poor in Velvet Seats}

When Chávez emerged on the political scene during the attempted coup in 1992, Venezuela's self-imagery as a racial democracy with a pacted class-compromise had been thoroughly shattered. When he a few years later ran as a presidential candidate, the poor saw in him the possibility to finally be represented by someone who didn't only understand them, but who also looked like them. With his mixed-race physical features and poor background, Chávez turned himself into the first statesman to not only speak for the poor, but also with them. As his presidency evolved, the poor and colored became increasingly visible in those public spaces that had been previously controlled and defined by the middle- and upper classes. Suddenly, they had access to media, to politicians, and to other arenas that were previously forbidden territory. Many times, people told me of how 
the pompous concert hall, Teresa Careño, in downtown Caracas, with its soft, red velvet seats, had suddenly become accessible to the poor classes. Not only was it being used for political meetings, but discount tickets were also sold for cultural events such as concerts, plays and operas. Previously, this concert hall was the exclusive space of the elites.

And never before had the poor classes been able to enter the offices of government ministries or of the National Assembly to directly talk to the decision-makers. Suddenly, the poor were at the center of the political agenda, and they could meet with politicians and even solicit their presence in meetings organized by the popular sector. No longer did they have to bow to power and privilege. The stigma of poverty had been removed and converted into a symbol of pride, strength and virtuousness. Gerardo, a young man in his late 20 s once told me of when he used to work as a delivery boy. Equipped with a motorbike, he ran errands for a company around town-a common occupation where mail services are highly deficient. He always felt so ashamed and intimidated when he walked into the nice office buildings. The employees would disapprovingly look at him and his grimy face covered with traffic dust. "Things had changed," he said. Poor people no longer felt ashamed.

For the middle and upper classes, who were used to having monopoly over defining social and political hegemony, this immense social and political change came as a shock. Not only was the country suddenly ruled by colored people that, in their eyes, were not capable or entitled to rule a country (Fernandes 2010:118), but all of a sudden poor people were imposing themselves across social and political spaces and claiming power and privileges. The wealthy homeowners in eastern Caracas complained that their maids and gardeners had become too demanding and assertive. As political tensions rose, the class and race cards were increasingly played by the wealthy to demonstrate their disgust with the government and its followers.

\section{Monkeys, Marginals and Mobs}

The racial dimension of their political disdain was evidenced in the frequent portrayal of Hugo Chávez, and other colored political leaders, as a monkey in cartoons. Moreover, government opponents frequently referred to Hugo Chávez as mico mandante. The expression is derived from mi comandante (my commander) - an expression Chávez's followers often used when referring to him, while mico is a small monkey. The 
expression thus translates to "monkey in charge." Some years back, the US embassy in Caracas hosted a party where the guests were entertained with a puppet show portraying Chávez as a gorilla. Colin Powell, the US foreign minister at the time, was not amused-perhaps for obvious reasons-and publicly reprimanded the embassy (Ali 2013). Monos (monkeys), hordas (hordes), chusma (lowlife, scum), turba (mob), marginales (marginals), ordinarios (simple) and lumpen (poor, vulgar, brute) were other expressions frequently used by government opponents when referring to supporters of the Chávez government. Another expression was that the government's supporters have a bozal de arepa (muzzle of arepa). The muzzle full of arepas is in this case used to suggest that the poor were silenced and fooled by government handouts. Another derogatory expression used to refer to poor people in general is tierruos, which comes from tierra (soil). The expression harks back to when the streets in the barrios weren't asphalted and a barrio inhabitant could be recognized because of his or her soil-covered feet upon entering the city center. Another term is pata en el suelo, simply meaning "hoofs on the ground," referring to a person who cannot afford to buy shoes and thus walks barefoot.

\section{Civil Society And Mobs}

Scholars have drawn attention to how both oppositional groups and affiliated private media consistently portray themselves as "civil society groups," whereas government supporters are described as hordes, mobs and scum (Fernandes 2010:118; Duno-Gottberg 2011). As Duno-Gottberg writes about how the private Venezuelan media portrayed the popular mobilization during the 2002 coup: "As a mob, they were undifferentiated, faceless" (Duno-Gottberg 2009:160). They were cast as barbaric, irrational and violent, and deprived of political rationale (Duno-Gottberg 2009:160). The "civil society" of the middle and upper classes in contrast, represented order, reason, modernity and prudence, exercising their political agency in manners consistent with legitimate middle-class citizenship in modern capitalist societies.

The imagery of the poor as a mob can also be found in a more recent story. This was experienced first-hand by a middle-class friend of mine. During the 2014 demonstrations and guarimbas (violent riots) carried out by oppositional middle-class youth and students, there were fears 
among middle-class citizens that government supporters would come to their neighborhoods to retaliate. At a meeting in one of the gated condominiums close to the city center, they were discussing how to defend themselves if their gates were attacked by furious barrio dwellers. The suggestion that many of the residents found the most attractive was that they would gather at the roof of the building and throw boiling cooking oil down at the invaders. The hordes never came.

\section{The Ideology of the Resentful}

Another recurrent middle-class template of Chávez's supporters is that they were resentidos (resentful) toward the rich, wanting what was not rightfully theirs at the expense of "hardworking" people. It is a common perception among the middle and upper classes that the poor are poor because they are lazy and incapable of "superarse y salir adelante" [improve themselves and move forward]. In contrast, the rich have what they have because of their hard work, and not because of inherited privileges, their birthed social position, or structural inequalities. Chavismo appealed to the poor, according to this perception, because it gave them handouts and fed upon the hatred toward the rich. For example, an op-ed in the Venezuelan daily newspaper El Universal, titled "La ideología del resentido" [the ideology of the resentful], read: "As a central strategy, the Señor President [Chávez] appeals to the abandonment of the marginal, making him feel valued and to a great extent feeding their hatred towards the richest" (Guerra 2009, author's translation from Spanish). Guerra's initial opinion of Chavista activists was that they were:

individuals without any style whatsoever ... lacking of any apparent education, and with a threatening and ragged expressions. In their slogans they emulate curses against opponents, defending a revolution they don't know, with hatred as a banner, vengeance as a motor and as principles and values .... They use weapons of all kinds against any march or convocation of the existing "oligarchy" and destruction is left in their wake, without any remorse whatsoever, nor basically any belief at all. (Guerra 2009, author's translation from Spanish)

The author then modified her view of Chávez's supporters, recognizing that among them are both educated and even intelligent people-though lacking "emotional intelligence." Now she has come to believe that being 
a Chavista is not a matter of education or money, but rather a matter of people who cuddle for some kind of traumatic experience of poverty or abandonment in life.

The views expressed in this op-ed eloquently sums up the different perceptions circulating among the middle and upper class about Chávez's supporters and poor people in general. Structural explanations of poverty have little resonance in this scheme. In line with conventional neoliberal individualistic ideology-not least social ideologies prevalent in the USA-it is believed that people have to accomplish themselves by their own efforts, and that poverty comes from inherent traits-laziness, passivity, sloth, resentment and envy. In this perspective, the Chávez government's redistribute efforts simply amounted to a strategy to win votes through cuddling up to a culture of poverty (Lewis 1966).

\section{Institutionalized Prejudices}

Nancy, a young and ambitious woman in her early 30s working as a teacher in a private school in the middle-class neighborhood of Altamira, frequently told me of how her mainly white middle-class colleagues and the children's mothers talked about government supporters and poor people in general. Nancy's school catered mainly to wealthier children, and Nancy had to be careful to disguise her political sympathy toward the government. In the stories of her work environment, everyday racism and class prejudices were abundant, evidencing that in spite of the political removal of the stigma attached to being poor and colored within the socio-political sphere of the government and its supporters, social spaces dominated by the middle and upper classes remained unchanged. One of the episodes that she recalled was a conversation she had with the former principal at her school, who nodding toward a colored pupil, said with barely hidden contempt: "Before, we didn't use to have negros here ... it's not like I am a racist, but you know...."

The Chávez government obliged private schools to admit pupils from the disadvantaged sectors of society. However, according to Nancy, schools did what they could to avoid it, or at least her school did. Nancy recounted that the school psychologists responsible for admissions had told her that they singled out those applicants whose parents didn't have a professional degree because "surely they cannot pay." They also singled out those children whose parents were likely to be Chavista (education, 
color and address being what gave them away) "because they would only create trouble." Nancy herself had never revealed that she was a Chavista. "They would kick me out, without a doubt. They would find any excuse to sack me," she said. "I think there are other teachers there who are Chavistas as well, but we never talk about it. We just find a way not to say anything if the other teachers (supporting the opposition) say something," she added. Nancy herself grew up in dire poverty in a shantytown in western Caracas, but through her mother's and her own enormous efforts and sacrifices, she managed to graduate as a geography and history teacher. She has a fairly light complexion and takes great care of, and spends a large portion of her income on, her appearance (hair, skin and clothing) so as to not evoke the scorn of her pupils. That was why she managed to get the job in the first place and also managed to keep it. She recalled that a substitute teacher with darker skin, curly hair revealing her African ancestry and clothing that revealed her less affluent background had been bullied so much by her pupils that she had resigned after a week.

\section{Class Resentments Reversed}

Derogatory labeling of the middle and upper classes also seeped into the political vocabulary of the government and of the popular classes. The commonly used term esqualido as a substantive for opposition supporters emerged in the midst of the political polarization after Chávez's election. Esqualido derives from the word squalid, or to be without morals, values and social conscience. Sifrino is a common term for middle-class opponents, referring to a person that is materialistic, snobbish, superficial and preposterous, and has questionable values and a lack of social conscience. It is worth noting that sifrino is not only used as a class attribute, but can also be used of a person that has a snobby appearance and certain consumption preferences. People from a humble background can also be called sifrinos if they try to be snobbish in their behavior or consumption (see Chap. 8). Oligarchia (oligarchy) and burgués (bourgeois) are commonly used class ascriptions within the leftistMarxist vocabulary.

Burgués is similar to sifrino while oligarchia is used to describe economic interest groups that are using covert and/or violent strategies to maintain their power and privileges. Similarly, golpistas (coup-mongers) 
and facistas (fascists) refer to the opposition's attempts to undermine the Chávez government with any means necessary, in particularly referring to the 2002 coup. Vendepatria (sellers of the fatherland) refers to the perceived attachment that the opposition/oligarchy has to external interests and their lack of loyalty to the interests of their homeland, both economically and spiritually. It is often said that the Venezuelan upper classes have their spiritual home in Miami. Not only was Miami the favored destination (and to a large extent still is) for middle- and upper-class shopping sprees during the Venezuela Saudita period of the 1970s, but it is also home to a large expat community that resembles the Cuban one in its virulent hostility toward Chávez and his supporters.

The degree of hostility between opposition and government supporters has changed with shifting political junctures. In the years following the coup in 2002 , levels of hostility ran particularly high, and families and friends reportedly became bitter enemies over political differences. The conflict levels have also hardened in the aftermath of Chávez's death and the election of Nicholas Maduro in 2013.

\section{Chávez, El Presidente and El Pana ${ }^{1}$}

Chávez's weekly Sunday shows, Aló Presidente, were undoubtedly crucial in shaping Chávez's relationship with his supporters. The live transmissions were filmed from across the country, as Chávez was touring the nation, visiting communities and inspecting government projects. There, he combined political analysis with historical lectures, anecdotes, jokes, songs, popular education and on-the-spot interaction with the audience. His ability to talk without a script was only comparable to that of Fidel Castro, and his pedagogical skills allowed him to present relatively dry policy topics in a way that captured even the most politically illiterate audience. Through these programs and other public appearances, people felt that they got to know Chávez the person. He became a man in the flesh, who was open about his feelings, apologized for his mistakes and shared generously from his personal life.

While it is tempting to characterize this form of communication as a merely populist strategy, Chávez's mass appeal cannot be reduced to a question of charisma, manipulation and demagoguery (Hellinger 2001:5). According to Alejandro Moreno, a Salesian priest and social psychologist who has lived in one of the barrios of Caracas for a long time: "What is important is not what he speaks but what speaks inside 
him. In him speaks the convivial relations of popular Venezuela, of convivial man ... an elderly woman expressed it very well: 'for me, it's like my own son is president" (Hellinger 2001:5). The intimacy that this elderly woman felt toward Chávez is telling of the general sentiments that he incited among his followers. Chávez appeared as a friend, a son or a neighbor. He was what Venezuelans colloquially call a jodedor, a person that doesn't take himself too seriously, who loves a good banter and knows how to tell a good story - the ideal person to have a beer with on your door step on a Friday afternoon. He was the anti-thesis to the kind of slick politicians that staged photo-shoots with the poor, kissing babies and squeezing the hands of old ladies trying to appear sympathetic to the plight of the disenfranchised. Chávez had been poor himself, and he was, as he once said describing his relationship with el pueblo, like a "fish in the water" (Ellner 2003:146).

\section{SONS AND DAughters OF Bolívar}

Yet, while Chávez was recognized as the "maximum leader" in that historical moment, his followers were not merely passive recipients of his political directives. When Chávez announced a new political vision or a significant new strategy, it would be subjected to analysis among activists. By highlighting people's power and emphasizing el pueblo as the sovereign, the poor felt enabled to appreciate and claim their own past, giving strength to a process of social organization from below. Like a housewife and activist from Catia in her 40s said to me as I was interviewing her in La Casa de Poder Popular (the house of people's power) in Propatria:

We, the Venezuelans, since this revolutionary process that El Comandante Hugo Chávez Frias is leading, is submerged in a profound knowledge and recognition of our history. For years, the social movements were treated as hordes, as unruly negros, as ignorant ... as uneducated, as uneducated without a fatherland ... when el pueblo has gathered and poured out in the streets, to do revolution, to break the chains ... it has taken place because that has been moments when el pueblo have been conscious of why they are taking to the streets...

This statement is representative of how "common people" articulated their newfound political subjectivities. "Bolivarian discourse," shared 
by housewives new to politics, long-term activists, and politicians alike, underscored that Chávez's greatest achievement was to enable the poor to appropriate a cultural, social and political space that was rightfully theirs for the first time in Venezuelan history.

What was seen as rightfully theirs in this context was also a quest for restoring "true" Venezuelanness and national dignity. As Rosa, an ardent Chávez's supporter in her 60s, worded it:

I have always rebelled against everything that goes against my country, not only now, but all my life, and like I say to people ... many people say to me in a condescending way, ah, you are a Chavista. And I say to them, hold on a minute, I am not a Chavista, I am venezolana, Bolivariana and revolucionaria (Venezuelan, Bolivarian and revolutionary), that is my way of thinking. And do I love Chávez? Yes, I do, because that man has done for this country what no one else has done.

To understand the meaning of Rosa's words, it is important to capture the national mythology surrounding Simón Bolívar, and the way that he has become both mythologized and reinterpreted into a Bolivarian narrative. In simple terms, Simón Bolívar embodies the historical quest for national sovereignty and social justice. The struggle that he was fighting against the Spanish colonizers equals the contemporary struggle against foreign domination and exploitation. One of Bolívar's most famous quotes is: "The United States seems destined by providence to plague Latin America in the name of liberty." 2 Accordingly, his master thought was the creation of a confederation of neighbouring countries called Gran Colombia which could constitute a counter-hegemonic force against North American dominance. Within the Bolivarian narrative, the Bolivarian process, leaded by Hugo Chávez, was the continuation of Bolívar's quest for independence. Bolívar was born into oligarchy, but turned against his own as he joined forces with freed slaves and peasants against the Spanish conquistadores. Per the Bolivarian narrative, his fight for the liberty of el pueblo was paralleled to the fight against the contemporary oligarchy in the name of the liberty and dignity of the popular sectors. Within this interpretative scheme, both the oligarchs of Bolívar's time and today's oligarchs are betraying Venezuela because they have since long been allied with, and benefited from the alliance with foreign exploiters at the nation's expense.

Often, prose is better equipped than academic analysis to communicate deep-seated national sentiments. I will therefore quote the lyrics of the folk singer, Alí Primera, that express the emotions associated with Bolívar. 


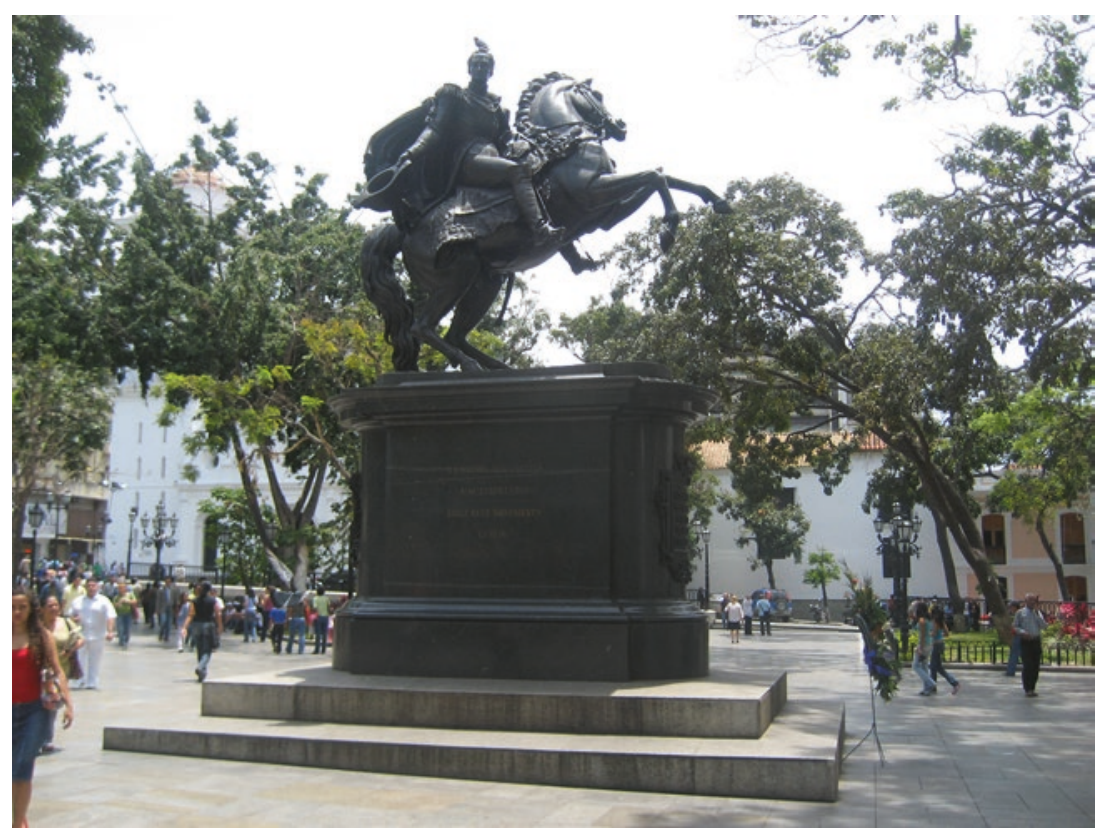

Photo 4.2 The statue of Simón Bolívar at Plaza Bolívar, downtown Caracas. Photo by the author

This is one of Primera's most famous songs, titled Sangueo para el Regreso (drumbeat for the return) ${ }^{3}$ :

El pueblo is wise and patient the elders are saying that when the guacharaca is singing ${ }^{4}$ they know how to calculate time

They say that the time is coming be alert, for when we will be happy Bolívar left yesterday but he is about to return

$$
\text { Let's go there }
$$
let's go meet him

They say that Bolívar is coming filled with rage and courage inside 


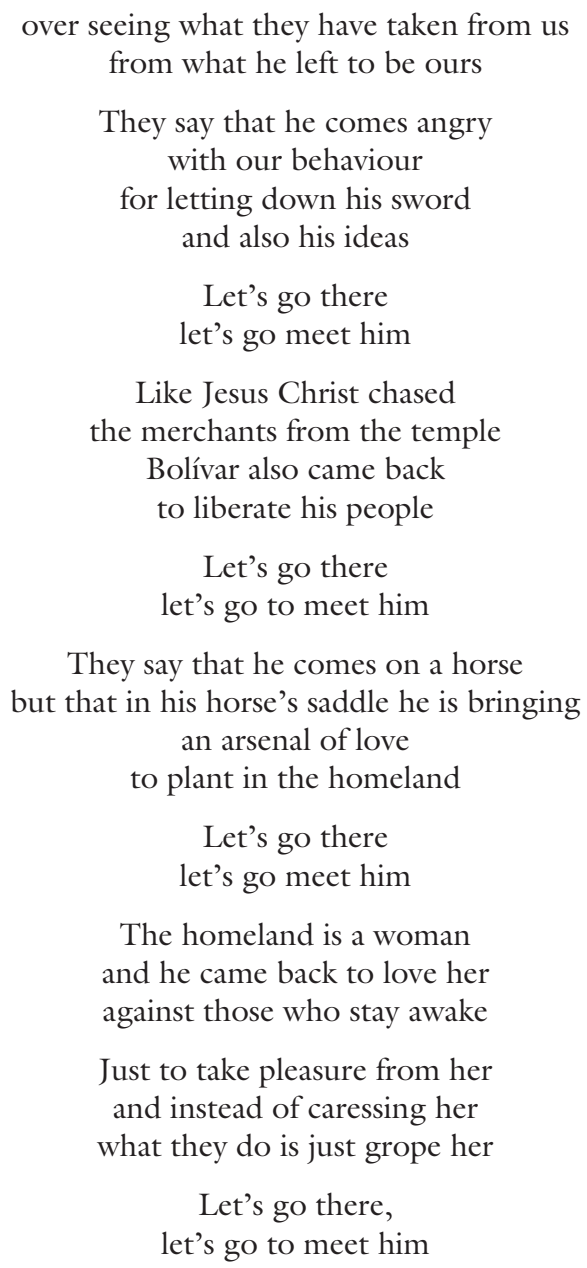

In this poem, Venezuela is referred to as a woman that has been exploited and pillaged by greedy "merchants," and el pueblo is portrayed as having betrayed the struggle and the legacy that Bolivar left them with. However, the poem also indicates that he will return to embrace them and continue the struggle. As an associated digression, it is worth recalling Pablo Neruda's poem "A Song for Bolívar," in which Bolívar says: "I wake up every hundred years when the people awake." The imagery of Bolívar looms large in Latin American leftist political consciousness, because per 
their political-ideological historical timeframe, the struggle for independence and liberty that Bolívar started has never been completed. When we now revisit Rosa's pledge to be venezolana, Bolivariana and revolucionaria we can better appreciate the multi-layered meaning of that statement, whereby she aligns her support for Chávez with an ongoing struggle for reconquering the nation's sovereignty and integrity.

Often, Latin American political symbolism is misunderstood by foreign observers. Drawing on more pathos and more mystique than what is usually allowed in Western political discourse, it is often interpreted as anti-modern and detrimental to political rationality. Chávez's evoking of Bolívar in his political discourse has occasionally been chided as a cultlike manipulation of national symbols. However, while these symbols and associations are central to the Bolivarian ideology, they can also be read as interpretative vehicles for articulating historical trajectories, political ideologies and social identities rather than as archaic narratives steeped in magical realism (but see Michelutti 2017).

\section{Caudillismo and Chávez's Charisma}

While, throughout this and in Chap. 3, I have sought to describe popular mobilization through the political and historical experiences of the popular sectors, it is also important to recognize the legacy of caudillo leadership in Latin America's political culture and the ways in which Chávez has been associated with this historical interpretation of leadership and rule.

The imagery of the caudillo originated from Latin America's tumultuous political history after colonialism, which revolved around regionalist and centralist struggles whereby military strongmen were "rising from power and falling from it, to be replaced by new seekers after power who rose and fell in turn" (Wolf and Hansen 1972:205). The caudillo is often envisioned as a brave, fearless, strong and armed man "on horseback," gaining power through his personal ability to muster followers through coercion, charisma or political visions, or a combination of the three. As Wolf and Hansen show, caudillismo has to be understood as a product of colonialism and post-colonial rule, forming certain configurations of political institutions, economic relations, territorial divisions, social stratifications and military power (Wolf and Hansen 1972:216-223). The historical role of the caudillo in political life rests on a particular form of Latin American personhood molded through machismo: independent, brave and 
with a dose of cruelty, dominant (both toward women and other men), shrewd and savvy (Wolf and Hansen 1972:224).

The imagery of caudillismo as a "one-man/strong-man rule" is often invoked in Latin American politics as proof of the fallback to "primitive" politics of the past. A Google search for Chávez + caudillo generates around 426,000 hits, evidencing the extent to which Chávez became associated with this political style. Certainly, Chávez's personal style resonated with the historical strong-man image-not least because of his military background. Both in charismatic terms and political terms, his government was very much centralized in the imagery of Chávez as the one man that had the strength to command the political change that the Bolivarian process entailed. Moreover, by invoking the figure of Bolívar, a larger-than-life icon of the "benevolent" caudillo in Venezuelan national mythology, the imagery of national salvation by the hands of one single man became even more bolstered.

However, as the discussions above have shown, people's relationship (real and imagined) with Chávez was both complex and nuanced. His public persona and relationship with "the masses" certainly had certain messianic and "caudillistic" qualities, but if we give that too much explanatory weigh, we lose out of sight people's own life histories, social identities and political agencies both prior to and after the arrival of Chávez. Just like the concept of "populism," "caudillismo" provides for a thin explanation when confronted with the complex reality of how people themselves related to Chávez and the Bolivarian process.

In this and the foregoing chapter, I have sought for a thick description (Geertz 1973) of people's relationship to Chávez and the Bolivarian process, while at the same time addressing the deeper origins of the political polarization that flared up in Venezuela after Chávez's arrival to power. In the chapters that follow, I will turn my attention toward the way in which people's emerging political identities and agencies were enacted in the context of everyday popular politics. Commentators frequently grouped all of Chávez's supporters into one and labeled them Chavistas. From an emic point of view, this is a mistake. While some people self-identified as Chavistas-meaning that their political loyalty and beliefs were founded in the figure of Chávez (also in the aftermath of his death)-others were careful to emphasize that they were 
not Chavistas. Rather they underscored that their support for Chávez's political project rested on the basis of a shared conviction of the necessity of social change and political struggle. The majority of Chávez's supporters looked at state politics with a critical eye, and their support for the government was not unconditional. Most activists were careful to underscore that it was not "Chávez's revolution," but rather a popular revolution whose success was dependent on people's capacity to appropriate the political space that had been opened up through the Chávez government. At the heart of this struggle was the articulation of popular power through grassroots activism and community organization. Chapter 5 starts with a reflection on how we may best understand community politics in the context of the Bolivarian process, followed by a minute examination of a case of long-term community mobilization in the Parish of 23 de Enero.

\section{Notes}

1. Pana is an informal Venezuelan word for "buddy" or "pal."

2. In Spanish: Los Estados Unidos parecen destinados por la Providencia a plagar la América de miserias en nombre de la libertad.

3. Author's translation from Spanish. Sangueo is a verb referring to the sound of tambores, African drums, and it is therefore not easily translated. Original lyrics can be found at http://www.musica.com/letras.asp?letra= 1093256.

4. The guacharaca is a small parrot that only sings at certain hours of the day.

\section{BiBLIOGRAPHY}

Ali, Tariq. 2013. Tariq Ali: Hugo Chávez and Me. The Guardian, March 16. http://www.theguardian.com/world/2013/mar/06/hugo-chavez-andme-tariq-ali. Accessed February 20, 2017.

BBC. 2012. In Depth: Media in Venezuela. www.bbc.co.uk, October 3. http:// www.bbc.co.uk/news/world-latin-america-19368807. Accessed February 20, 2017.

Caldeira, Teresa. 2000. City of Walls. Crime, Segregation, and Citizenship in São Paulo. Berkeley: University of California Press.

Coronil, Fernando, and Julie Skurski. 2006. States of Violence. Ann Arbor: University of Michigan Press.

Derham, Michael. 2010. Politics in Venezuela. Explaining Hugo Chávez. Oxford, Bern, Berlin, Bruxelles, Frankfurt am Main, New York, Wien: Peter Lang. 
Duno-Gottberg, Luis. 2009. Social Images of Anti-Apocalypse: Bikers and the Representation of Popular Politics in Venezuela. Contracorriente 6 (2): $144-172$.

- 2011. The Colour of Mobs. Racial Politics, Ethnopopulism, and Representation of the Chávez Era. In Venezuela's Bolivarian Democracy. Participation, Politics and Culture under Chávez, ed. D. Smilde and D. Hellinger. Durham and London: Duke University Press.

Ellner, Steve. 2003. The Contrasting Variants of the Populism of Hugo Chávez and Alberto Fujimori. Journal of Latin American Studies 35 (1): 139-162.

Fernandes, Sujatha. 2010. Who Can Stop the Drums? Urban Social Movements in Chávez' Venezuela. Durham and London: Duke University Press.

Geertz, Clifford. 1973. The Interpretation of Cultures. New York: Basic Books, Inc.

Guerra, Natacha. 2009. La ideología del resentido. El Universal, February 13. http://www.eluniversal.com/opinion/090213/la-ideologia-del-resentido. Accessed February 20, 2017.

Harrison, Faye. 1995. The Persistent Power of "Race" in the Cultural and Political Economy of Racism. Annual Review of Anthropology 24: 47-74.

Hellinger, Daniel. 2001. Tercermundismo and Chavismo. Revised version of paper delivered at Meeting of the Latin American Studies Association, Washington, DC, September 2-8.

Hoffman, Kelly, and Miguel Angel Centeno. 2003. The Lopsided Continent: Inequality in Latin America. Annual Review of Sociology 29: 363-390.

Lewis, Oscar. 1966. La Vida: A Puerto Rican Family in the Culture of Poverty. San Juan and New York. New York: Random House.

Michelutti, Lucia. 2017. "We Are All Chávez": Charisma as an Embodied Experience. Latin American Perspectives 44 (1): 232-250.

Mullings, Leith. 2005. Interrogating Racism: Toward an Antiracist Anthropology. Annual Review of Anthropology 34: 667-693.

Sapiezynska, Ewa. 2017. The Media and Power in Postliberal Venezuela: The Legacy of Hugo Chávez for the Debate on Freedom of Expression. Latin American Perspectives 44 (1): 199-214.

Schiller, Naomi. 2011. Catia Sees You: Community Television, Clientelism, and the State in the Chávez Era. In Venezuela's Bolivarian Democracy. Participation, Politics and Culture under Chávez, ed. D. Smilde and D. Hellinger. Durham and London: Duke University Press.

Tinker, Miguel S. 2009. The Enduring Legacy. Oil, Culture, and Society in Venezuela. Durham and London: Duke University Press.

UNDP. 2010. Acting on the Future. Breaking the Intergenerational Transmission of Inequality. The Regional Human Development Report for Latin America and the Caribbean 2010, UNDP, United Nations. http://hdr.undp.org/en/content/acting-future. Accessed February 20, 2017. 
Weissbrot, Mark, and Tara Ruttenberg. 2010. Television in Venezuela: Who Dominates the Media? Center of Economic and Policy Research. http://cepr. net/documents/publications/2010_12_venezuela_media.pdf. Accessed June 11, 2017.

Wolf, Eric, and Edward Hansen. 1972. The Human Condition in Latin America. New York, London and Toronto: Oxford University Press.

Wright, Winthrop. 1990. Café con Leche. Race, Class and National Image in Venezuela. Austin: University of Texas Press.

Open Access This chapter is distributed under the terms of the Creative Commons Attribution 4.0 International License (http://creativecommons.org/licenses/ by $/ 4.0 /$ ), which permits use, duplication, adaptation, distribution and reproduction in any medium or format, as long as you give appropriate credit to the original author(s) and the source, provide a link to the Creative Commons license and indicate if changes were made.

The images or other third party material in this chapter are included in the chapter's Creative Commons license, unless indicated otherwise in a credit line to the material. If material is not included in the chapter's Creative Commons license and your intended use is not permitted by statutory regulation or exceeds the permitted use, you will need to obtain permission directly from the copyright holder.

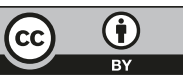

